\title{
PROBLEMS OF B.ED. TEACHER TRAINEES: A SURVEY
}

\author{
Dr. Rajesh R. Rathod ${ }^{1 *}$ \\ *l Principal, Shree Nivash Ramanujan Primary School, Surat, Gujarat, India. E-mail: raja3822@yahoo.co.in
}

*Corresponding Author: -

E-mail: raja3822@yahoo.co.in

\begin{abstract}
: -
In the present study Researcher tried to identify the problems of B.Ed. Teacher trainees. Random sampling technique was used for selecting the sample. The total sample was that of 90 B.Ed. Teacher trainees from three B.Ed. colleges. Researcher used Survey method in this study. The collected data were analyzed by using the qualitative research methods. Results shows that Lack of fluency in the language of instruction, Lack of ICT related subject in curriculum, In-Ability to create and sustain an effective learning environment, Students feel stage fear after the experience of forty stray lessons and New teaching techniques were not used in instructional process. Separate rooms were not provided for every method. Transport facility was not provided to students by the management. Some college don't have LCD projector. Lack of expert teachers. Lack of Proper guidance for preparing qualitative lesson plan. Lesson Planning format were no change. Lack of subject wise teaching aids in every college and various useful equipments in Psycho lab for teaching psychology. Most of the colleges don't have sufficient numbers of teaching aids and reference books in the library. Sometimes librarians' behavior is problematic for students. Lack of arrangement of the Campus interview by College and Expert lectures for the development of Student.
\end{abstract}

Keywords: - Teacher trainees, qualitative research, teaching techniques, sampling, stray lessons.

\section{(c) $(\$)$}




\section{INTRODUCTION}

Teacher education is a difficult assignment, especially at the present stage where teacher education programmes are being delivered by a large number of unaided private teacher education institutions. A lot of planning and resources has been spent for solving the problems as well as improving the quality of teacher education. New technologies have been introduced in the field of education; still our teacher-education has not risen to the expected level. It is lacking in realizing its purpose. Kothari Commission remarks "The destiny of India is being shaped in its classrooms." No doubt education plays a significant role in nation's development but the quality of education is greatly determined by the quality of teachers, therefore, great efforts were made and still are being made to improve the quality of teacher education. Researchers try to know the problems concerning teacher education especially among B.Ed. teacher trainees.

\section{Objectives Of the Study}

1. To identify problems faced by B.Ed. Teacher Trainees related to the Teaching-Learning process.

2. To identify problems faced by B.Ed. Teacher Trainees related to the Physical Facility.

3. To identify problems faced by B.Ed. Teacher Trainees related to Lesson plan preparation.

4. To identify problems faced by B.Ed. Teacher Trainees related to the Teaching Aid.

5. To identify problems faced by B.Ed. Teacher Trainees related to the library.

6. To identify the other problems faced by B.Ed. Teacher Trainees.

\section{Questions Of the Study}

1. What are the problems faced by B.Ed. Teacher Trainees related to the Teaching-Learning process?

2. What are the problems faced by B.Ed. Teacher Trainees related to the Physical Facility?

3. What are the problems faced by B.Ed. Teacher Trainees related to Lesson plan preparation?

4. What are the problems faced by B.Ed. Teacher Trainees related to the Teaching Aid?

5. What are the problems faced by B.Ed. Teacher Trainees to the Library?

6. What are the other problems faced by B.Ed. Teacher Trainees?

\section{Population and Sample of The Study}

All the trainees of B.Ed. College affiliated to Veer Narmad South Gujarat University; Surat were the population of this study.

According to random sampling technique three B.Ed. Colleges were selected from the 33 B.Ed. colleges of V.N.S.G.University. From each B.Ed. colleges 30 trainees were selected randomly from each college and total 90 trainees were selected for data collection

\section{Research Method}

As per need data were to be collected from the field, Educational Survey method was used for the study.

\section{Tools Of the Research}

The researcher used open ended questionnaire to collect the data from the sample of B.Ed. Teacher Trainees. These questions were related to each of the areas mentioned in the objectives or questions. Trainees responded to the questionnaire administered to them.

\section{Data Analysis}

Collected data was analyzed by qualitative analysis. Content Analysis technique was used for data analysis.

\section{Findings}

1. Teaching-Learning process related problems faced by B.Ed. Teacher Trainees are as under:

- Most of the lecturers use lecture method in classroom teaching it means lack of new teaching methods.

- Lack of fluency in the language of instruction

- Lack of ICT related subject in curriculum.

- In-Ability to create and sustain an effective learning environment.

- Students feel stage fear after the experience of forty stray lessons.

- New teaching techniques were not used in instructional process.

- Lack of use of ICT in classroom.

\section{Physical Facility related problems of B.Ed. Teacher Trainees are as under:}

- Lack of usefulness of Psychology lab, Science lab and Computer lab throughout the year.

- Lack of training related to ICT teaching Aids.

- Separate rooms were not provided for every method.

- Transport facility was not provided to students by the management.

- Some college don't have LCD projector.

3. Lesson plan related problems of B.Ed. Teacher Trainees are as under:

- Lack of expert teachers.

- Lack of Proper guidance for preparing qualitative lesson plan. 
- Lesson Planning format were no change.

- Lack of specific training for preparing to good lesson planning.

- School for their stray lessons was very far from the college.

4. Teaching Aids related problems of B.Ed. Teacher Trainees are as under:

- Lack of subject wise teaching aids in every college.

- Most of the colleges don't have sufficient numbers of teaching aids.

- Lack of various useful equipments in Psycho lab for teaching psychology.

- Lack of useful chemical and basic equipments in Science lab for teaching.

5. Library related problems of B.Ed. Teacher Trainees are as under:

- Lack of sufficient numbers of reference books in the library.

- There is no reference book for Hindi or English medium students.

- Sometimes librarians' behavior is problematic for students.

- No change issue-returns system in Library.

- Lack of qualified staff.

5. Other problems of B.Ed. Teacher Trainees are as under:

- Lack of arrangement of the Campus interview by college.

- Lack of Expert lectures for the development of Student.

- Lack of planning for personality development class for the students coming from the backward area.

- Essay type question in examination takes more time so do change the format of Question paper.

\section{Conclusion}

Teacher and his education are very significant aspects of any nation. The education gives a new shape to the individual and the nation as well. It is a well known saying that teacher is the nation builder. If we provide very good infrastructure, Physical facility, Library facility, Proper guidance for lesson planning and help them to solve their problems than develop proper skills in our Teacher Trainees.

\section{References}

[1].Desai, Ashok. J. (2012). Problems of Teacher Education In India. International Journal for Research in Education (IJRE), Vol.1, Issue: 1, p 54-58.

[2].Kothari, D. S. (1966). Report of the Education Commission (1964-66). Govt. of India, New Delhi.

[3].Shah, D. B. (2004). Educational Research. Ahmadabad: Pramukh Prakasan.

[4].Taneja, R.P. (2000). Encyclopedia of Comparative Education. Anmol Publications Pvt. Ltd., New Delhi.

[5].Vashist, S.R. (2003). Professional Education of Teachers. Jaipur: Mangal Deep. 